\title{
Deposit of pesticides without and with adjuvants on citrus seedlings following different intervals of artificial rain
}

\author{
Depósito de caldas fitossanitárias sem e com adjuvantes sobre mudas de \\ citros com diferentes intervalos para incidência de chuva artificial
}

\section{Ricardo Augusto Decaro $^{\mathrm{I}^{*}}$ Sergio Tadeu Decaro Junior ${ }^{\mathrm{I}}$ Marcelo da Costa Ferreira ${ }^{\mathrm{I}}$}

ABSTRACT

For a crop protection product to achieve its goal the product must be applied and remain on the leaves until it is absorbed. This situation may be compromised due to rainfall after spraying, thus necessitating reapplication which increase the overall cost. Application technology research has focused on alternatives and solutions to mitigate this effect through the use of adjuvants. The objective of this research was to evaluate the deposit of spraying liquid on citrus seedlings using the products spirodiclofen, propargite, imidacloprid, lambda cyhalothrin, copper oxychloride, and copper hydroxide with water mixed with the adjuvants polydimethylsiloxane and phosphatidylcholine. Seedlings were subjected to simulated rains of $10 \mathrm{~mm}$ at intervals of $1,6,12$ and $24 \mathrm{~h}$ after spraying, and the remaining deposits of spraying liquid per leaf area were analyzed by spectrophotometry by assessing a metallic marker previously added in the spraying liquids. Variables were subjected to analysis of variance and Tukey's test $(P<0.05)$. The rains that occurred soon after spraying resulted in decreased spraying liquids deposits on citrus leaves. Adjuvant phosphatidylcholine promoted the greatest retention of spraying liquid on citrus leaves after rainfall.

Key words: fungicides, insecticides, miticides, pulverization, application technology.

RESUMO

A aplicação de um produto fitossanitário deve assegurar que ocorra sua chegada e permanência das gotas sobre folhas até que sejam absorvidos para manifestação do efeito biológico. Essa situação pode ser comprometida pela ocorrência de chuvas após a pulverização, necessitando de reaplicações que elevam os custos. A tecnologia de aplicação busca alternativas e soluções para amenizar esse efeito, como o uso de adjuvantes. Objetivou-se, neste trabalho, avaliar o depósito de caldas fitossanitárias pulverizadas sobre mudas de citros, com os produtos espirodiclofeno, propargite, imidacloprido, lambida cialotrina, oxicloreto de cobre e hidróxido de cobre apenas com água e em mistura com os adjuvantes polidimetilsiloxano e fosfatidilcoline antes e após chuvas artificais de $10 \mathrm{~mm}$, com intervalos de 1, 6, 12 e 24 horas após a pulverização. Os depósitos de caldas remanescentes por área foliar foram analisados por espectrofotometria, considerando um marcador metálico previamente adicionado nas caldas. As variáveis foram submetidas à análise de variância e ao teste de Tukey $(P<0,05)$. As chuvas ocorridas mais próximas do momento das pulverizações resultaram em menores depósitos de calda sobre as folhas de citros. $O$ adjuvante fosfatidilcoline manteve a maior quantidade das caldas sobre folhas de citros, quando da ocorrência de chuvas após a pulverização.

Palavras-chave: fungicidas, inseticidas, acaricidas, pulverização, tecnologia de aplicação.

\section{INTRODUCTION}

Citrus culture is one of the most demanding applications of spraying liquids in Brazil. The use of correct technologies in spraying is

\footnotetext{
'Núcleo de Estudos e Desenvolvimento em Tecnologia de Aplicação (NEDTA), Departamento de Fitossanidade, Faculdade de Ciências Agrárias e Veterinárias (FCAV), Universidade Estadual Paulista (UNESP), Via de acesso Professor Paulo Donato Castellane, s/n, 14884-900, Jaboticabal, SP, Brasil. E-mail: ricardo decaro@hotmail.com. "Corresponding author.
} 
extremely important, especially to protect against the mite vector of the citrus leprosis virus, Brevipalpus phoenicis (GEIJSKES, 1936) (Trombidiformes: Tenuipalpidae); the fungus that causes citrus black spot (Guignardia citricarpa Kiely, 1948); and the vector of Huanglongbing (HLB), the psyllid Diaphorina citri (Kuwayama, 1908) (Hemiptera: Psyllidae) (SPÓSITO et al., 2004). Inaccurate dosing of products and the appropriate choice of the application rate, the spray tip, and the equipment and the optimal time to apply the treatment are among the problems encountered by farmers.

To minimize errors during the application, many recent developments have explored the suitability of equipment to the shape of plants, the study of the optimum droplet size and the deposition of spraying liquids through the careful selection of nozzles and adjuvants (FERREIRA et al., 2013a).

Some adjuvants, when mixed with the spraying liquids, promote increased scattering droplets on the treated surfaces. Each adjuvant possesses different properties with respect to surface tension, viscosity, stability and the affinity of the liquids and the treated surfaces (CALORE et al., 2014).

The frequent seasonal rainfall in Brazil poses a challenge to the application of spraying liquids on crops. The influence of rainfall after spraying varies according to its quantity and intensity, the interval between the application of the product and the rainfall, the characteristics of the surface of the leaves of the treated crop, and the plant protection product used and its solubility in water; thus, much of the application product may be lost during rainfall (AKOBUNDU, 1987; HANCE \& HOLLY, 1990; CABRAS et al., 2001; GREEN, 2001; DECARO JUNIOR et al., 2013).

In light of these factors, the objective of this study was to evaluate the deposit of plant protection products and adjuvants on citrus seedlings subjected to different intervals of artificial rain.

\section{MATERIAL AND METHODS}

Citrus seedlings of 'Pêra' sweet orange (Citrus sinensis (L.)) were obtained from certified producers, These seedlings are uniform in architecture and, at 12 months old, has an average of 20 leaves and a plant height of $60 \mathrm{~cm}$. The seedlings were planted in plastic bags with dimensions of $10 \mathrm{x}$ $30 \mathrm{~cm}$ that contained treated soil, sand, and humus. Spraying was performed using two fungicides widely used in citrus production for the control of diseases such as citrus black spot; two insecticides used to control psyllid, HLB vector and other insects; and two miticides used to control the mite vector of citrus leprosis virus and other mites. Fungicides used were Cuprogarb $500^{\circledR}$ (copper oxychloride) at a dosage of $200 \mathrm{~g}$ of product per $100 \mathrm{~L}$ of water and Supera ${ }^{\circledR}$ (copper hydroxide - inorganic) at a dosage of $150 \mathrm{ml}$ of product per $100 \mathrm{~L}$ of water. Insecticides used were Kohinor $^{\circledR}$ (imidacloprid) at a dosage of $20 \mathrm{ml}$ of product per $100 \mathrm{~L}$ of water and engeo Pleno ${ }^{\circledR}$ (lambdacyhalothrin + thiamethoxam) at a dosage of $15 \mathrm{ml}$ of product per $100 \mathrm{~L}$ of water. Finally, the acaricides used were Envidor $^{\circledR}$ (spirodiclofen) at a dosage of $25 \mathrm{ml}$ of product per $100 \mathrm{~L}$ of water and Acarit $^{\circledR}$ (propargite) at a dosage of $100 \mathrm{ml}$ of product per $100 \mathrm{~L}$ of water.

Two adjuvants were added to each of the six products: polydimethylsiloxane (Vertex $\mathrm{RS}^{\circledR}$ ) at a dosage of $20 \mathrm{ml}$ of the product per $100 \mathrm{~L}$ of water and phosphatidylcholine plus propionic acid (LI700 ${ }^{\circledR}$, formulation emulsifiable concentrate - EC), at a dosage of $500 \mathrm{ml}$ of product per 100 liters of water; plant protection products with water was used as a control. In all, 18 pesticides were formed.

Analysis of spraying liquids deposits in citrus leaves

Two experiments were conducted at Universidade Estadual Paulista - UNESP, Jaboticabal campus, São Paulo State, Brazil at different times. In each experiment, one of the 18 spraying liquids was sprayed on a group containing 15 citrus seedlings. The first experiment was conducted on January $9^{\text {th }}$, 2013. Relative humidity of the air on this day ranged from $85 \%$ to $79 \%$, while the temperature ranged from $22.5^{\circ} \mathrm{C}$ to $27^{\circ} \mathrm{C}$. Wind speed was constant at approximately $4-7 \mathrm{~km} \mathrm{~h}^{-1}$. The second experiment took place on August 19 ${ }^{\text {th }}, 2013$, with relative humidity between $78 \%$ and $58 \%$, temperature between 21.8 and $24^{\circ} \mathrm{C}$, and a wind speed between 4 and $7 \mathrm{~km} \mathrm{~h}^{-1}$.

A metallic marker formulated on the basis of manganese sulfate $\left(31 \%\right.$ of $\left.\mathrm{Mn}^{2+}\right)$ was added to the spraying liquids at a dosage of $3 \mathrm{~g} \mathrm{l}^{-1}$ in the first experiment and $10 \mathrm{~g}^{-1}$ in the second experiment. The higher dose was applied to reduce the interference of external factors on the treatment once the seedlings of 
the second experiment had traces of manganese in their leaves, thus achieving greater reliability in the results.

The seedlings were sprayed with the spraying liquids until the leaves reached the point of maximum liquid retention, from which occurred runoff. The equipment used included a backpack sprayer pressurized at $506.8 \mathrm{kPa}$ by $\mathrm{CO}_{2}$ with a model TX-18 spray nozzle. After spraying, 2 leaves were collected from the 3 seedlings (replications) of each treatment, totaling 54 plants

One hour after spraying, other group of 54 seedlings, contemplating the same treatments, were arranged under an artificial rainfall and received $10 \mathrm{~mm}$ of rain over 6.25 minutes. The procedure was repeated with the other seedlings after 6,12 and 24 hours.

Rainfall simulator was equipped with six model FL10 spray nozzles $\left(\right.$ TeeJet $\left.^{\circledR}\right)$, producing extremely large drops spaced every 0.25 meters evenly in a circular tube. Formed droplets hit the ground and created a wetted area of approximately $1.75 \mathrm{~m}^{2}$, with good uniformity and distribution; the indicators CUC and CUD exceeded $90 \%$. The simulator was located $2.87 \mathrm{~m}$ from the ground and worked at a pressure of $137.8 \mathrm{kPa}$

The two leaves collected from each seedling composed a sample and were placed in plastic bags for transport to the laboratory for further analysis. In each plastic bag, $150 \mathrm{ml}$ of $0.2 \mathrm{~N} \mathrm{HCl}$ solution was added, and the sample was kept at rest for 60 minutes to allow the dissolution of the manganese marker that was deposited on the leaves at the time of spraying. After the dissolution, the resulting extracts were filtered one by one and packed in containers to analyze the concentration of $\mathrm{Mn}^{2+}$ ions by means of atomic absorption spectrophotometry. Concurrently, the surface area of the leaves used to obtain the extracts was measured using an LI-3100C Area Meter $\left(\right.$ LI-Cor $\left.{ }^{\circledR}\right)$. Manganese concentrations that were obtained with the spectrophotometer were related to the measured leaf areas, resulting in the concentration of manganese per square centimeter of leaf.

In both experiments, a sample of leaves was collected from four random citrus seedlings before spraying to check for the presence of $\mathrm{Mn}^{2+}$ remaining from previous treatments. Quantities obtained were subtracted from the value of all of the readings of the treatments in the first and second experiment, respectively, so as to only consider the effect of the treatments. Values in $\mu \mathrm{g}$ of $\mathrm{Mn}^{2+}$ per $\mathrm{cm}^{2}$ of leaf were processed into spraying liquid volume per area, in unit of $\mu \mathrm{l}$ per $\mathrm{cm}^{2}$, once the concentration of the element in the spraying liquids was known.

In addition to the spraying liquid deposition data in the citrus leaves before and after the intervals of artificial rain, the percentage of spraying liquid that remained on the leaves after the intervals of artificial rain was also analyzed.

The experiments were analyzed in a factorial of $6 \times 3 \times 5$, with three replications. The data were submitted to an analysis of variance, and the means were compared using Tukey's test $(\mathrm{P}<0.05)$.

\section{RESULTS AND DISCUSSION}

Deposit quantity as a function of different spraying liquids In the first experiment, it was determined that, on average, $0.04 \mu \mathrm{g}$ of $\mathrm{Mn}^{2+}$ per $\mathrm{cm}^{2}$ of leaf remained on the seedlings before spraying, whereas in the second experiment, $1.38 \mu \mathrm{g} \mathrm{Mn}^{2+}$ per $\mathrm{cm}^{2}$ remained on the leaves. These values were subtracted from the readings of the marker deposit for the respective experiments; thus, the subsequent results were not overestimated. These $\mathrm{Mn}^{2+}$ readings reflect the residue of the cultural treatments previously applied to the seedlings or to the naturally presence nutrient in the plants.

In the experiments, the spraying liquids mixed with plant protection products without adjuvants resulted, in general, in larger deposited volumes, except for the Propargite product, in which the use of polydimethylsiloxane resulted in the highest deposit (Figure 1). This effect of the adjuvants is consistent with the results reported by other authors for other adjuvants (ANDRADE et al., 2010; SOARES et al., 2013).

Treatments containing the adjuvant phosphatidylcholine resulted in a significantly lower mean spraying liquid deposit compared with the treatment with polydimethylsiloxane and the control without adjuvant (Figure 1). Phosphatidylcholine resulted in lower spraying liquid volume retained by the leaves due to the intrinsic characteristics of this surfactant, which is classified as a spreader-sticker. Similar results were reported by DECARO JUNIOR et al. (2013).

The polydimethylsiloxane adjuvant resulted in intermediate spraying liquid deposit values compared with the average of the treatments with 


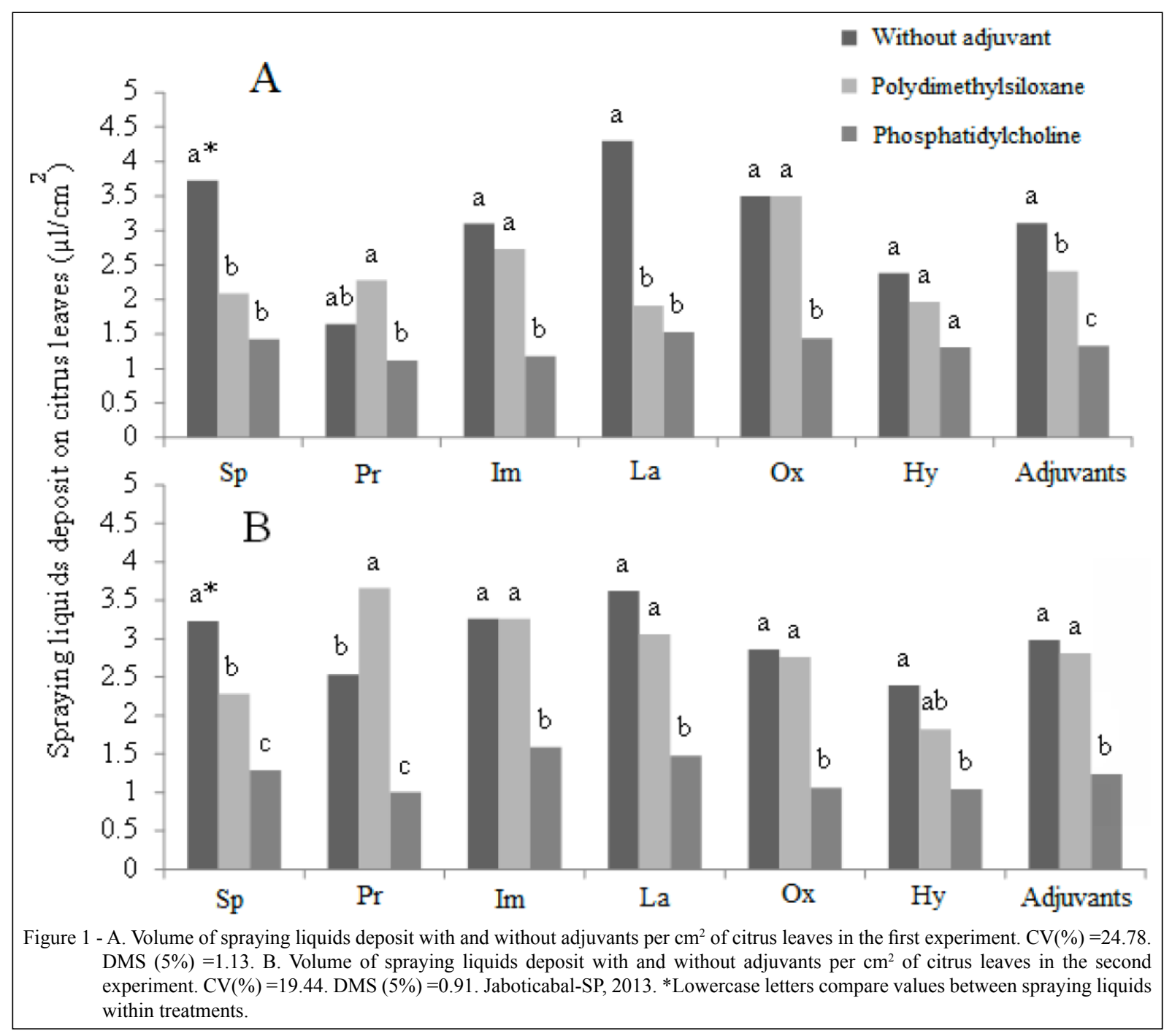

phosphatidylcholine and without adjuvant. The effect of this product was more pronounced in retaining the spraying liquid on the leaf surface when compared with phosphatidylcholine.

Spraying liquids sprayed with copper hydroxide in both experiments resulted in similar deposits with and without adjuvants in the mixture. This fungicide already contains an adjuvant in its original composition, which decreases the influence of the external use of other adjuvants (LASMAR et al., 2012; DECARO JUNIOR et al., 2013).

Spraying liquid deposits after intervals of artificial rain In both experiments, it was determined that the larger deposits of the spraying liquids on the citrus leaves were obtained in the absence of rain, whereas rains after 1, 6, 12 and 24 hours significantly decreased the deposited amount (Tables 1 and 2).

The remaining deposits on the leaves after rains at intervals of 1 and $6 \mathrm{~h}$ were similar in both experiments, except for Propargite product mixed with polydimethylsiloxane in the second experiment, where there were lower average deposit values spraying liquid (Tables 1 and 2). In both experiments, the rains that occurred 1 and $6 \mathrm{~h}$ after spraying resulted in lower spraying liquids deposits; however, in some cases, the deposit values did not differ significantly from the other intervals (Tables 1 and 2).

Rain simulations that occurred closest to the application of the spraying liquid significantly

Ciência Rural, v.46, n.1, jan, 2016. 
Table 1 - Spraying liquid deposit in citrus leaves expressed in iL.cm ${ }^{-2}$ shortly after spraying $(0 \mathrm{~h})$ and after the artificial rain $(1,6,12$ and 24 h). First experiment. Jaboticabal-SP, 2013.

\begin{tabular}{|c|c|c|c|c|c|c|}
\hline \multirow{2}{*}{ Product } & \multirow{2}{*}{ Adjuvant } & \multicolumn{5}{|c|}{$\mu \mathrm{L} \mathrm{cm}^{-2}-$} \\
\hline & & $0 \mathrm{~h}^{*}$ & $1 \mathrm{~h}$ & $6 \mathrm{~h}$ & $12 \mathrm{~h}$ & $24 \mathrm{~h}$ \\
\hline \multirow{3}{*}{ Spirodiclofen } & - & 3.73 & $0.99 \mathrm{a} \mathrm{B}^{1}$ & $1.22 \mathrm{a} \mathrm{AB}$ & $2.05 \mathrm{a} \mathrm{A}$ & $1.12 \mathrm{a} \mathrm{B}$ \\
\hline & Polydimethyl $^{2}$ & 2.09 & 0.62 a B & $0.76 \mathrm{a} A B$ & $1.60 \mathrm{a} \mathrm{AB}$ & $1.6 \mathrm{a} \mathrm{A}$ \\
\hline & Phosphatidyl $^{3}$ & 1.44 & $0.52 \mathrm{a} \mathrm{B}$ & 0.72 a $\mathrm{AB}$ & $0.87 \mathrm{a} A B$ & $1.52 \mathrm{a} \mathrm{A}$ \\
\hline \multirow{3}{*}{ Propargite } & - & 1.65 & 0.77 a A & 0.97 a A & $1.02 \mathrm{a} \mathrm{A}$ & $1.16 \mathrm{a} \mathrm{A}$ \\
\hline & Polydimethyl $^{2}$ & 2.28 & 0.92 a A & 0.95 a A & $1.53 \mathrm{a} \mathrm{A}$ & $1.26 \mathrm{a} \mathrm{A}$ \\
\hline & Phosphatidyl $^{3}$ & 1.12 & 0.24 a A & 0.49 a A & $1.05 \mathrm{a} \mathrm{A}$ & 0.81 a $\mathrm{A}$ \\
\hline \multirow{3}{*}{ Imidacloprid } & - & 3.1 & 0.93 a $\mathrm{A}$ & $1.35 \mathrm{a} \mathrm{A}$ & $1.82 \mathrm{a} \mathrm{A}$ & $1.73 \mathrm{a} \mathrm{A}$ \\
\hline & Polydimethyl $^{2}$ & 2.73 & 0.73 a $\mathrm{A}$ & $1.38 \mathrm{a} \mathrm{A}$ & $1.07 \mathrm{ab} \mathrm{A}$ & $0.91 \mathrm{ab} \mathrm{A}$ \\
\hline & Phosphatidyl $^{3}$ & 1.18 & 0.83 a $\mathrm{A}$ & 0.68 a A & $0.99 \mathrm{~b} \mathrm{~A}$ & $0.74 \mathrm{~b} \mathrm{~A}$ \\
\hline \multirow{3}{*}{ Lambda-cyhalothrin } & - & 4.3 & $1.12 \mathrm{a} \mathrm{AB}$ & 0.94 a B & $1.29 \mathrm{a} \mathrm{AB}$ & $1.91 \mathrm{a} \mathrm{A}$ \\
\hline & Polydimethyl $^{2}$ & 1.91 & $0.61 \mathrm{a} \mathrm{A}$ & 0.6 a A & 0.93 a A & $0.86 \mathrm{~b} \mathrm{~A}$ \\
\hline & Phosphatidyl $^{3}$ & 1.53 & 0.6 a A & 0.48 a A & 0.6 a A & $0.87 \mathrm{~b} \mathrm{~A}$ \\
\hline \multirow{3}{*}{ Copper oxychloride } & - & 3.5 & $1.43 \mathrm{a} \mathrm{A}$ & $1.97 \mathrm{a} \mathrm{A}$ & $1.6 \mathrm{a} \mathrm{A}$ & $1.49 \mathrm{a} \mathrm{A}$ \\
\hline & Polydimethyl $^{2}$ & 3.5 & $1.61 \mathrm{a} \mathrm{A}$ & $1.05 \mathrm{~b} \mathrm{~A}$ & $1.41 \mathrm{a} \mathrm{A}$ & $1.53 \mathrm{a} \mathrm{A}$ \\
\hline & Phosphatidyl ${ }^{3}$ & 1.44 & 0.8 a A & $0.48 \mathrm{~b} \mathrm{~A}$ & $0.96 \mathrm{a} \mathrm{A}$ & $1.12 \mathrm{a} \mathrm{A}$ \\
\hline \multirow{3}{*}{ Copper hydroxide } & - & 2.38 & $1.12 \mathrm{a} \mathrm{A}$ & 0.92 a A & 0.89 a A & $0.67 \mathrm{~b} \mathrm{~A}$ \\
\hline & Polydimethyl $^{2}$ & 1.97 & 0.89 a A & $1.01 \mathrm{a} \mathrm{A}$ & $1.4 \mathrm{a} \mathrm{A}$ & $1.59 \mathrm{a} \mathrm{A}$ \\
\hline & Phosphatidyl $^{3}$ & 1.31 & 0.81 a A & 0.67 a A & 0.93 a A & $1.02 \mathrm{ab} \mathrm{A}$ \\
\hline Dms $5 \%{ }^{4}$ & & 0.9 & 0.9 & 0.9 & 0.9 & 0.9 \\
\hline Dms $5 \%^{5}$ & & 0.82 & 0.82 & 0.82 & 0.82 & 0.82 \\
\hline $\mathrm{CV} \%$ & & 40.63 & 40.63 & 40.63 & 40.63 & 40.63 \\
\hline
\end{tabular}

${ }^{1}$ Averages followed by the same lowercase in the column and the same uppercase letter in the line does not differ by $5 \%$ Tukey test. ${ }^{2}$ Adjuvant polydimethylsiloxane. ${ }^{3}$ Adjuvant phosphatidylcoline. Minimum Significant Difference for column and line ${ }^{5}$.

*Treatments before being submitted to artificial rain differ significantly.

reduced the spraying liquid volume that remained deposited on the leaves (Figure 2). Foliage of the plants was saturated with the spray, requiring several hours to dry. Therefore, the rains that occurred closest to the application were more efficient in reducing the deposited volume on the leaves because the spraying liquids were composed almost exclusively of water.

Our results demonstrate that $10 \mathrm{~mm}$ of rain, at all intervals after application was sufficient to significantly decrease the percentage of deposited spraying liquid. This implies the need for a new spray that will restore the quantity of leachate products, resulting in higher costs. Some studies involving other cultures and spraying liquids have demonstrated that rains of low intensity and short intervals after spraying are sufficient to compromise the effectiveness of the plant protection treatment, making the use of certain adjuvants critical (MATEUS et al, 2004; GASKIN \& STEELE, 2009; PANNACCI et al, 2010; FORTUNATO et al., 2011; ECHER \& ROSOLEN, 2012).

For samples subjected to rain six hours after the spray, the percentage of spraying liquid that remained deposited on the leaves for samples without adjuvants and samples with polydimethylsiloxane or phosphatidylcholine was $45 \%, 49 \%$, and $59 \%$, respectively, in the first experiment. Thus, phosphatidylcholine promoted the retention of spraying liquid significantly more effectively than 
Table 2 - Spraying liquid deposit in citrus leaves expressed in i $\mathrm{L} \mathrm{cm}^{-2}$ shortly after spraying $(0 \mathrm{~h})$ and after the artificial rain $(1,6,12$ and 24 h). Second experiment. Jaboticabal-SP, 2013.

\begin{tabular}{|c|c|c|c|c|c|c|}
\hline \multirow{2}{*}{ Product } & \multirow{2}{*}{ Adjuvant } & \multicolumn{5}{|c|}{$-\mu \mathrm{L} . \mathrm{cm}^{-2}-$} \\
\hline & & $0 \mathrm{~h}^{*}$ & $1 \mathrm{~h}$ & $6 \mathrm{~h}$ & $12 \mathrm{~h}$ & $24 \mathrm{~h}$ \\
\hline \multirow{3}{*}{ Spirodiclofen } & - & 3.23 & $1.29 \mathrm{a} \mathrm{AB}^{1}$ & 0.58 a B & $1.15 \mathrm{a} \mathrm{AB}$ & $1.61 \mathrm{a} \mathrm{A}$ \\
\hline & Polydimethyl $^{2}$ & 2.28 & $1.07 \mathrm{ab} \mathrm{A}$ & $0.75 \mathrm{a} \mathrm{A}$ & $0.41 \mathrm{a} \mathrm{A}$ & $0.92 \mathrm{ab} \mathrm{A}$ \\
\hline & Phosphatidyl $^{3}$ & 1.29 & $0.27 \mathrm{~b} \mathrm{~A}$ & $0.43 \mathrm{a} \mathrm{A}$ & 0.79 a A & $0.58 \mathrm{~b} \mathrm{~A}$ \\
\hline \multirow{3}{*}{ Propargite } & - & 2.54 & 0.68 a A & $0.6 \mathrm{~b} \mathrm{~A}$ & $0.66 \mathrm{~b} \mathrm{~A}$ & $1.18 \mathrm{a} \mathrm{A}$ \\
\hline & Polydimethyl $^{2}$ & 3.66 & 0.38 a C & $1.4 \mathrm{a} \mathrm{AB}$ & $2.27 \mathrm{a} \mathrm{A}$ & $1.25 \mathrm{a} \mathrm{BC}$ \\
\hline & Phosphatidyl $^{3}$ & 1 & $0.41 \mathrm{a} \mathrm{A}$ & $0.29 \mathrm{~b} \mathrm{~A}$ & $0.45 \mathrm{~b} \mathrm{~A}$ & $0.63 \mathrm{a} \mathrm{A}$ \\
\hline \multirow{3}{*}{ Imidacloprid } & - & 3.26 & $1.27 \mathrm{a} \mathrm{A}$ & $1.49 \mathrm{ab} \mathrm{A}$ & $1.39 \mathrm{a} \mathrm{A}$ & $1.7 \mathrm{a} \mathrm{A}$ \\
\hline & Polydimethyl $^{2}$ & 3.26 & $1.16 \mathrm{ab} \mathrm{A}$ & $2.00 \mathrm{a} \mathrm{A}$ & $1.59 \mathrm{a} \mathrm{A}$ & $1.42 \mathrm{ab} \mathrm{A}$ \\
\hline & Phosphatidyl $^{3}$ & 1.59 & 0.45 a A & $0.77 \mathrm{~b} \mathrm{~A}$ & $0.42 \mathrm{~b} \mathrm{~A}$ & $0.67 \mathrm{~b} \mathrm{~A}$ \\
\hline \multirow{3}{*}{ Lambda-cyhalothrin } & - & 3.62 & $1.55 \mathrm{a} \mathrm{A}$ & $1.39 \mathrm{a} \mathrm{A}$ & $1.15 \mathrm{a} \mathrm{A}$ & $1.14 \mathrm{a} \mathrm{A}$ \\
\hline & Polydimethyl $^{2}$ & 3.06 & $0.53 \mathrm{~b} \mathrm{~A}$ & 0.59 a $\mathrm{A}$ & $0.6 \mathrm{a} \mathrm{A}$ & $1.04 \mathrm{a} \mathrm{A}$ \\
\hline & Phosphatidyl $^{3}$ & 1.48 & $0.35 \mathrm{~b} \mathrm{~A}$ & 0.86 a A & 0.44 a A & $0.38 \mathrm{a} \mathrm{A}$ \\
\hline \multirow{3}{*}{ Copper oxychloride } & - & 2.86 & $1.38 \mathrm{a} \mathrm{AB}$ & $0.62 \mathrm{a} \mathrm{B}$ & $1.98 \mathrm{a} \mathrm{A}$ & $1.51 \mathrm{a} \mathrm{A}$ \\
\hline & Polydimethyl $^{2}$ & 2.76 & $1.15 \mathrm{ab} \mathrm{A}$ & $1.02 \mathrm{a} \mathrm{A}$ & $0.97 \mathrm{~b} \mathrm{~A}$ & $1.26 \mathrm{ab} \mathrm{A}$ \\
\hline & Phosphatidyl $^{3}$ & 1.06 & $0.36 \mathrm{~b} \mathrm{~A}$ & 0.82 a A & $0.31 \mathrm{~b} \mathrm{~A}$ & $0.51 \mathrm{~b} \mathrm{~A}$ \\
\hline \multirow{3}{*}{ Copper hydroxide } & - & 2.39 & 0.9 a A & $1.13 \mathrm{a} \mathrm{A}$ & $1.04 \mathrm{a} \mathrm{A}$ & $1.31 \mathrm{a} \mathrm{A}$ \\
\hline & Polydimethyl $^{2}$ & 1.82 & 0.77 a A & 0.97 a A & 0.77 a A & $0.76 \mathrm{a} \mathrm{A}$ \\
\hline & Phosphatidyl $^{3}$ & 1.04 & 0.44 a A & $0.5 \mathrm{a} A$ & $0.6 \mathrm{a} \mathrm{A}$ & $0.57 \mathrm{a} \mathrm{A}$ \\
\hline Dms $5 \%{ }^{4}$ & & 0.8 & 0.8 & 0.8 & 0.8 & 0.8 \\
\hline Dms $5 \%^{5}$ & & 0.88 & 0.88 & 0.88 & 0.88 & 0.88 \\
\hline $\mathrm{CV} \%$ & & 45.11 & 45.11 & 45.11 & 45.11 & 45.11 \\
\hline
\end{tabular}

${ }^{1}$ Averages followed by the same lowercase in the column and the same uppercase letter in the line does not differ by $5 \%$ Tukey test. ${ }^{2}$ Adjuvant polydimethylsiloxane. ${ }^{3}$ Adjuvant phosphatidylcoline. Minimum Significant Difference for column and line ${ }^{5}$. *Treatments before being submitted to artificial rain differ significantly.

the other two treatments $(\mathrm{F}=8.28 * *: \mathrm{LSD}=8.80$; $\mathrm{CV}=43.72 \%$ ). In the second experiment, $41 \%, 38 \%$ and $46 \%$ of the spray liquid remain in samples without adjuvants and in samples with polydimethylsiloxane and phosphatidylcholine, respectively; the difference was not significant $\left(\mathrm{F}=2,32^{\text {ns. }}\right.$, $\left.\mathrm{DMS}=8,40 ; \mathrm{CV}=51 \%\right)$. The adhesive effect of phosphatidylcholine resulted in a greater volume deposited on the leaf surface of citrus seedlings after artificial rain.

Although polydimethylsiloxane adjuvant is classified as a protector against the action of rain, in both experiments, its effect did not differ from the control without adjuvants. The use of the high volume sprayed on plants could explain this behavior; in other studies, polydimethylsiloxane was effective in promoting the retention of spraying liquid even after rainfall (FERREIRA et al., 2013b).

\section{CONCLUSION}

The effect of rain on the retention of spraying liquid deposits (miticides, insecticides and fungicides) on citrus seedlings was reduced with increasing durations between spraying and rainfall. The adjuvant phosphatidylcholine promoted better retention in spraying liquid deposits on the citrus seedlings after different intervals of artificial rain. 


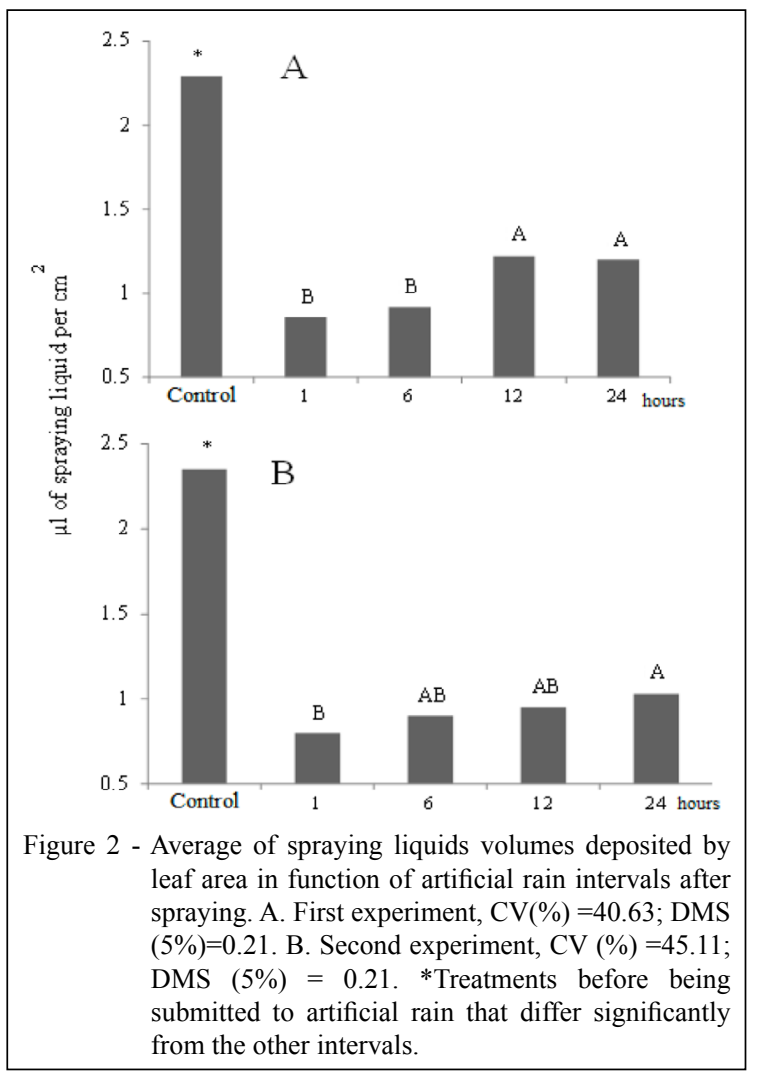

\section{ACKNOWLEDGEMENTS}

We thank the Fundação de Amparo à Pesquisa do Estado de São Paulo (FAPESP) for the financial support during the experiment, process number 2012/19709-7.

\section{REFERENCES}

AKOBUNDU, I.O. Weed Science in tropics: principles and practices. Chichester: John Wiley \& Sons, 1987. 105p.

ANDRADE, D.J. et al. Efeito da adição de óleos ao acaricida cyhexatin sobre o ácaro Brevipalpus phoenicis e na retenção de calda por folhas de citros. Revista Brasileira de Fruticultura, Jaboticabal, v.32, n.4, p.1055-1063, 2010.

CABRAS, P. et al. The effect of simulated rain on folpet and mancozeb residues on grapes and on vine leaves. Journal of environmental Science and Health, New York, v.36, n.5, p.609-618, 2001.

CALORE, R.A. et al. Effect of herbicides associated with adjuvants in surface tension and contact angle in leaves of Ipomoea hederifolia. Aspects of Applied Biology, Wellesbourne, v.122, p.425-420, 2014. Available from: <http://www.fcav.unesp.br/ Home/departamentos/fitossanidade/lapar/portugues-/p11-calore--effect-of-herbicides.pdf>. Accessed: May 05, 2014.
DECARO JUNIOR, S.T. Avaliação de um pulverizador de volume ultra baixo na cultura do café para o controle de leucoptera coffeella (Lepidoptera: lyonetiidae). 2013. 102f. Dissertação (Mestrado em Agronomia) - Faculdade de Ciências Aárias e Veterinárias, Universidade Estadual Paulista "Júlio de Mesquita Filho", Jaboticabal, SP.

ECHER, F.R.; ROSOLEM, C.A. Plant growth regulator losses in cotton as affected by adjuvants and rain. Ciência Rural, Santa Maria, v.42, n.12, p.2138-2144, 2012.

FERREIRA, M.C. et al. Deposição de calda inseticida com e sem óleo vegetal sobre mudas de citros em função de chuva artificial. In: CONGRESSO BRASILEIRO DE FITOSSANIDADE, 2., 2013, Jaboticabal, SP. Anais eletrônicos... Jaboticabal: Universidade Estadual Paulista, 2013a. p.722-725.

FERREIRA, M.C. et al. Qualidade da aplicação de inseticida em amendoim (Arachis hypogaea L.), com e sem adjuvantes na calda, sob chuva simulada. Bioscience Journal, Uberlândia, v.29, n.5, p.1431-1440, 2013b. Supl.1.

FORTUNATO, R.P. et al. Simulate rain about action insecticide flonicamid in the control of the cotton aphid. Acta Scientiarum. Agronomy, v. 33, n.4, p.603-606, 2011.

GASKIN, R.E.; STEELE, K.D. A comparison of stickers adjuvants for their effects on retention and rainfastness of fungicide sprays. New Zealand Plant Protection, New Zealand, v.62, p.339-342, 2009.

GREEN, J.M. Factors that influence adjuvant performance. In: INTERNATIONAL SYMPOSIUM ON ADJUVANTS FOR AGROCHEMICALS, 60., 2001, Amsterdam. Proceedings... Amsterdam: ISAA, 2001. p.179-190.

HANCE, R.J.; HOLLY, K. The properties of herbicides. In: Weed control handbook: principles. 8.ed. HANCE, R.J.; HOLLY, K. (Eds.). Oxford: Blackwell Scientific Publications, 1990. Chap.3. p.75-125.

LASMAR, O. et al. Retention of copper hydroxide spraying liquids with adjuvants on coffee plant leaves. In: INTERNATIONAL CONFERENCE ON COFFEE SCIENCE, 24., 2012, San Jose. Proceedings... [Cali: DAPA/CIAT], 2012. p.1067-1070.

MATEUS, G.P. et al. Perdas de cloreto de mepiquat no algodoeiro por chuva simulada. Pesquisa Agropecuária Brasileira, Brasília, v.39, n.7, p.631-636, 2004.

PANNACCI, E. et al. Effect of adjuvants on the rainfastness and performance of tribenuron-methyl on broad-leaved weeds. Weed Biology and Management, Japan, v.10, p.126-131, 2010.

SOARES, A.M.L. et al. Determinação da retenção de líquido, tensão superficial e ângulo de contato de gotas a partir de caldas com oxicloreto de cobre sobre folhas de laranja. In: CONGRESSO BRASILEIRO DE FITOSSANIDADE, 2., 2013, Jaboticabal, SP. Proceedings... Jaboticabal: Universidade Estadual Paulista, 2013. p.649-652.

SPÓSITO, M.B. et al. Elaboração e validação de escala diagramática para avaliação da severidade da mancha preta em frutos cítricos. Fitopatologia Brasileira, Brasília, v.29, p.81-85, 2004. 